\title{
Tar vi tuberkulose på alvor?
}

I Norge registreres det hvert år noe over 300 nye tilfeller av tuberkulose. Av disse forekommer omtrent $90 \%$ blant utenlandsfødte (Karin Rønning, Folkehelseinstituttet, personlig meddelelse). Nesten alle innvandrerne er smittet før de kommer til Norge, og de er unge, i motsetning til de norskfødte, som stort sett er eldre. Noen få norskfødte blir smittet under utenlandsopphold. I perioden 2001-11 kom 806 fra Somalia, 587 fra Norge, 200 fra Pakistan, 145 fra Etiopia, 120 fra Filippinene, 109 fra Vietnam, 99 fra Thailand, 76 fra Eritrea og 75 fra Afghanistan (totalt 3061 tilfeller). For 2011 er det funnet fire personer med multiresistent tuberkulose (MDR-TB), det vil si at stammen er resistent mot både rifampicin og isoniazid (Karin Rønning, personlig meddelelse). Vi har med andre ord et stabilt antall og foreløpig et lite problem med multiresistens.

I 2010 var det ifølge WHO 8,8 millioner nye tilfeller av tuberkulose og 1,1 millioner dødsfall. Globalt har forekomsten av tuberkulose vært fallende siden 2002. Fire av WHOs verdensregioner ser ut til å klare målet om å halvere dødeligheten fra 1990 til 2015, mens Afrika henger etter (1). WHOs europeiske region utgjøres av Europa, Russland og de tidligere sovjetrepublikkene. Den gjennomsnittlige prevalensraten i dette området har falt fra ca. 90 per 100000 i 1990 til ca. 70 i 2010 (1). Frem til 2015 forventes et ytterligere fall ned mot 60 .

Ved første øyekast ser det altså ut som om det går riktig vei. Men nedgangen i tuberkulosefrekvens skjuler en skremmende tendens. I vår region, WHOs europeiske region, ble det diagnostisert 28000 tilfeller av multiresistent tuberkulose, men det reelle tallet er anslått til 81000 . De 15 landene med høyest andel multiresistent tuberkulose er alle innenfor denne regionen (2). Dette skyldes ikke minst økende forekomst av såkalte Beijing-stammer. De utgjør 6-7\% av de følsomme stammene, men forårsaker hele $85 \%$ av tilfellene med multiresistent tuberkulose.

Behandling av multiresistent tuberkulose seiler nå opp som den store utfordringen. I de fleste nasjonale tuberkuloseprogrammene i høyendemiske land startes det med førstelinjemedikamenter uten resistenstesting. En enda mer resistent sykdomsgruppe er såkalt utvidet multiresistent tuberkulose (XDR-TB), der bakteriene i tillegg er resistente mot et aminoglykosid og et fluoroquinolon. På verdensbasis anslår man rundt 25000 nye tilfeller av XDR-TB i året. Mens ikke-resistent tuberkulose koster omtrent 120 kroner for seks måneders behandling, koster behandlingen av multiresistent tuberkulose 30000 kroner og mer. Utgiftene til kontroll for multiresistent tuberkulose vil i 2015 være 16 ganger høyere enn de midlene som i dag er tilgjengelige (1). I de fleste fattige land er behandling for multiresistent tuberkulose i praksis ikke tilgjengelig. I 2008 hadde $28 \%$ av nye pasienter i vårt naboområde Nordvest-Russland multiresistente former for tuberkulose. Hvordan møter vi utfordringen? For det første må vi oppdage nye tilfeller raskt. En studie viste at det tok omtrent 60 dager fra en pasient med aktiv lungetuberkulose begynner å hoste til diagnosen ble stilt (3). Det første vi må gjøre er altså å øke bevisstheten rundt tuberkulose $\mathrm{i}$ helsevesenet og i befolkningen.

For det andre bør vi endre tilnærmingen ved screening. Nå konsentrerer man seg om risikogrupper som asylsøkere, innvandrere og deres barn, men også etniske nordmenn med lange utenlandsopphold bør følges opp. Når det gjelder hva slags verktøy som bør benyttes er meninger og praksis delte. Et nytt verktøy i screeningen er de såkalte Interferon Gamma Realease Assays (IGRA) med gjennomgående over $90 \%$ sensitivitet og nær $100 \%$ spesifisitet. Likevel går de nasjonale anbefalingene ennå ut på at man først skal teste med mantouxprøven og så bekrefte med IGRA-analyse dersom mantouxprøven er positiv. Til forsvar for dette hevder man at prøven har høy sensitivitet i populasjoner med høy prevalens, det vil si innvandrerbefolkningen. Folkehelseinstituttet utreder hvorvidt grensen for hva som er positiv mantouxprøve skal senkes til $6 \mathrm{~mm}$, og mener dette vil bedre sensitiviteten. Personlig mener jeg dette er å gå baklengs inn i fremtiden. Slike justeringer har vært diskutert i alle år, og en senking av grenseverdien (cut-off) vil bare øke det som er tuberkulintestens grunnleggende problem: lav spesifisitet på grunn av kryssreaksjon med miljøbakterier og BCG. Det er vist at mantouxprøven kan gi opptil $40 \%$ falskt negative svar (4). Den nåværende totrinnsmodellen vil dermed kunne unnlate å fange opp nesten halvparten av de infiserte. Dette synes jeg er uakseptabelt.

En ny PCR-basert test kalt Xpert MTB/RIF viser en forbløffende høy sensitivitet direkte i sputum. Denne testen påviser også rifampicinresistens, og svaret kommer etter en time, slik at man nå kan tilpasse regimet fra dag 1. I land der dyrking og resistensbestemmelse ikke har vært tilgjengelig, er dette rett og slett en revolusjon. I Norge vil testen kunne spare liggedøgn og føre til raskere behandlingsoppstart for de sputumnegative. Ennå har vi under $3 \%$ multiresistent tuberkulose i Norge, men ut ifra den foruroligende utviklingen i WHOs europeiske region kan vi regne med at dette tallet vil øke, og med dette vårt behov for rask påvisning av resistens.

Endelig er det viktig at vi ikke bare ser til oss selv. Vi har både et moralsk ansvar og en egennytte av å bistå de landene som sliter med en tuberkuloseepidemi ute av kontroll. Her er vi godt i gang gjennom samarbeidet på Nordkalotten. Men også mange av de andre landene som våre nye landsmenn kommer fra, trenger vår ekspertise og også vår økonomiske støtte. Vi kan sannsynligvis bistå med å behandle 100 tilfeller i Somalia for prisen av det det koster å behandle én pasient etter at han banker på døren vår her i Norge. I en globalisert verden er vi alle i samme båt og Mycobacterium tuberculosis anerkjenner ingen landegrenser.

\section{Dag Storla}

dagstorla@gmail.com

Infeksjonsmedisinsk seksjon

Lovisenberg Diakonale Sykehus

Dag Storla (f. 1962) er dr.med. og overlege ved infeksjonsmedisinsk seksjon ved Lovisenberg Diakonale Sykehus. Han er spesialist i infeksjonssykdommer med tuberkulose som spesialfelt. Ingen oppgitte interessekonflikter.

\section{Litteratur}

1. Global tuberculsis control 2011. Genève: WHO, 2011. www.who.int/tb/ publications/global report/2011/gtbr11 full.pdf (9.12.2011).

2. World TB Day 2011 fact sheet. Genève: WHO, 2010. www.euro.who.int/en/ what-we-do/health-topics/communicable-diseases/tuberculosis/activities/ world-tb-day/world-tb-day-2011-fact-sheet (9.11.2011).

3. Farah MG, Rygh JH, Bjune $\mathrm{G}$ et al. Patient and health care system delays in the start of tuberculosis treatment in Norway. BMC Infect Dis 2006; 6: 33.

4. Nienhaus A, Schablon A, Bâcle CL et al. Evaluation of the interferon-gamma release assay in healthcare workers. Int Arch Occup Environ Health 2008; 81 295-300. 